\title{
PENGELOLAAN UNIT PRODUKSI SMK NEGERI RUMPUN BANGUNAN DI DAERAH ISTIMEWA YOGYAKARTA (STUDI KASUS SMKN 2 PENGASIH KULONPROGO)
}

\author{
Ahmad Gunadi \\ SMK Negeri 2 Pengasih Kulonprogo Yogyakarta \\ ahmadgunadi56@gmail.com \\ Husaini Usman \\ SMK Negeri 2 Pengasih Kulonprogo Yogyakarta \\ husainiusman@gmail.com
}

\begin{abstract}
Abstrak
Penelitian bertujuan untuk mengungkapkan: perencanaan, pengorganisasia, pelaksanaan, dan pengawasan unit produksi Jurusan Teknik Konstruksi Kayu di SMKN 2 Pengasih, Kulonprogo. Penelitian ini merupakan penelitian kualitatif dengan pendekatan studi kasus. Subjek penelitian ini adalah pengelola unit produksi, yang meliputi: Ketua UPJ, Ketua UPJ sekolah, dan Kepala Bengkel. Teknik pengumpulan data adalah wawancara, observasi dan dokumen. Analisis data melalui pemilahan data, reduksi data, penyajian data, dan penarikan kesimpulan. Hasil penelitian: perencanaan belum dilakukan dengan baik; kendala tidak ada rapat rutin dan lemahnya dokumentasi; tidak semua pengelola terlibat; pengorganisasian belum cukup baik; kendala dalam personalia, sarana dan peralatan yang kurang serta koordinasi; langkah-langkah pelaksanaan lebih menyerupai proses produksi; unit produksi belum berfungsi dengan baik sebagai sarana belajar; pelaksanaan terkendala bengkel yang sekaligus menjadi tempat praktik; langkah dan prinsip pengawasan diterapkan dalam pelaporan keuangan; pihak yang melakukan pengawasan yaitu ketua UPJ Sekolah, ketua UPJ jurusan, dan kepala bengkel; pengawasan terkendala pada tidak adanya SOP.
\end{abstract}

Kata Kunci: pengelolaan, unit produksi

\section{THE MANAGEMENT OF PRODUCTION UNIT OF VOCATIONAL HIGH SCHOOL IN THE FIELD OF BUILDING PROGRAM IN SPECIAL REGION OF YOGYAKARTA (A CASE STUDY OF SMKN 2 PENGASIH KULONPROGO)}

\begin{abstract}
This research is aimed to reveal: the planning, the organizing, the implementation, and the controlling of the production unit of Wood Construction Engineering Department of SMKN 2 Pengasih, Kulonprogo District. The research was qualitative with the case study approach. The subjects of the research were the managers of production unit, including; the managers of UPJ, the head of the school's UPJ, and the head of the workshop of wood construction. The technique used in the data collection was interviews, observations and documents. The data analysis was conducted by the stages of the data selection, data reduction, data presentation, and conclusions drawing. The results of the research; the planning has not been implemented optimally; the obstacles in the planning, i.e. the absence of regular meetings, specifically those discussing and the lack of documentations; not all the managers are involved; the organizing involves the distribution of the tasks, the delegation of tasks and authorities, as well as coordination; the obstacles in the personnel, inadequate facilities and infrastructure as well as the coordination; the implementation measures indicate the implementation functions applied are more like the implementation of the production process; the production unit has not functioned properly as a educational tool; the implementation is constrained by the workshop which also becomes a practicum place; the steps and the principles of supervision are only applied in terms of financial statements; the parties supervising the UPJ are the managers of the school UPJ, the managers of the department UPJ, and the head of the workshop; the supervision is constrained to the absence of SOP
\end{abstract}

Keywords: management, production unit. 


\section{PENDAHULUAN}

Pendidikan di Indonesia secara umum telah mengalami perkembangan yang lebih baik serta mempunyai peranan yang sangat penting dalam menjamin kelangsungan hidup negara karena pendidikan merupakan sarana untuk meningkatkan dan mengembangkan kualitas sumber daya manusia. Sumber daya manusia yang kompeten dan handal akan dapat meningkatkan kemampuan suatu bangsa dalam segala hal. Sumber daya manusia tersebut dibutuhkan dalam rangka pemenuhan kebutuhan tenaga kerja di dunia usaha dan dunia industri untuk mendukung pertumbuhan suatu bangsa.

Undang-undang Sistem Pendidikan Nasional nomor 20 tahun 2003 tentang Sistem Pendidikan Nasional, dalam pasal 1 ayat 1 menyebutkan bahwa pendidikan adalah usaha sadar dan terencana untuk mewujudkan suasana belajar dan proses pembelajaran agar peserta didik secara aktif mengembangkan potensi dirinya untuk memiliki kekuatan spiritual keagamaan, pengendalian diri, kepribadian, kecerdasan, akhlak mulia, serta keterampilan yang diperlukan dirinya, masyarakat, bangsa dan negara. Pendidikan merupakan suatu proses untuk mengembangkan potensi diri bagi setiap peserta didik sehingga nantinya dapat memiliki keterampilan, kecerdasan maupun kepribadian yang dibutuhkan oleh masyarakat maupun bangsa. Potensi diri yang dikembangkan merupakan modal bagi manusia yang sangat diperlukan dalam perkembangan dan pertumbuhan suatu bangsa dan negara.

Jenjang pendidikan yang bisa meluluskan peserta didik yang siap kerja, siap berwirausaha dan siap untuk melanjutkan pendidikan yang lebih tinggiadalah Sekolah Menengah Kejuruan (SMK). Salah satu kebijakan yang dikeluarkan oleh Kementerian Pendidikan dan Kebudayaan adalah pendidikan sistem ganda yang ada di SMK yang disebut juga dengan link and match. Kebijakan tersebut telah dilaksanakan di semua SMK yang ada, sehingga peserta didik telah dikenalkan tentang industri yang relevan dengan program pelatihan yang ada di sekolah. Walaupun pelaksanaan yang ada di lapangan masih terdapat beberapa hal yang perlu diperbaiki.
Pendidikan Sistem Ganda (PSG) merupakan suatu bentuk penyelenggaraan pendidikan keahlian profesional, yang memadukan secara sistematik dan sinkron antara program pendidikan di sekolah dan program yang ada di dunia industri atau dunia kerja yang diperoleh melalui kegiatan langsung di dunia kerja untuk mencapai suatu tingkat keahlian profesional. Dengan melaksanakan kegiatan tersebut maka peserta didik akan mendapatan beberapa unsur yang penting yaitu pengatahuan yang lebih luas dari pengalaman tersebut, teknik-teknik yang akan diperlukan di dunia kerja serta kiat-kiat yang berhubungan dengan keahlian di dunia industri dan dunia kerja.

Program pendidikan sistem ganda perlu didukung oleh berbagai pihak, di antaranya pihak industri sebagai patner dari sekolah, pihak masyarakat, dan pihak sekolah selaku pelaksana yang selalu memonitor proses pelaksanaan program tersebut. Semua pihak yang terkait mestinya selalu memberikan pengawasan terhadap program yang dilaksanakan. Salah satu program yang dapat membantu pendidikan sistem ganda adalah adanya praktik kerja di dunia industri, selain itu keberadaan unit produksi di masingmasing jurusan yang ada di sekolah juga dapat memberikan kontribusi yang baik terhadap program tersebut. Unit produksi merupakan suatu usaha untuk memanfaatkan peralatan sekolah secara optimum serta dapat memberikan keterampilan bagi pelaku unit produksi yang dalam hal ini adalah peserta didik dan guru yang ada di sekolah.

SMK merupakan sekolah yang di dalamnya lebih menekankan kepada pembelajaran produktif yang akan menghasilkan suatu produk maupun akan membuka peluang dengan jasa yang mereka miliki, sehingga akan menghasilkan produk-produk yang dapat dijual maupun dapat menerima pesaan sesuai dengan keinginan pemesan. Unit produksi yang ada di SMK sudah sangat relevan dengan kondisi yang ada di sekolah masing-masing.

Unit produksi sekolah selain dapat memberikan nilai tambah bagi sekolah juga dapat memberikan bekal bagi peserta didik tentang keterampilan-keterampilan yang harus 
dikuasai ketika akan memasuki dunia kerja, sehingga peserta didik akan lebih terampil dalam persaingan di dunia kerja. Selain itu bagi guru juga akan menambah kompetensi mereka sesuai dengan bidang masing-masing, dan juga akan menambah kesejahteraan bagi sekolah.

Fokus pembelajaran di SMK pada saat ini tidak hanya untuk mempersiapkan lulusan memasuki dunia industri atau dunia kerja namun juga mempersiapkan lulusan agar dapat melanjutkan pendidikan ke jenjang yang lebih tinggi dan dapat berwirausaha. Salah satu penunjang kegiatan pembelajaran di sekolah adalah adanya unit produksi yang ada di sekolah. Kajian tentang pengelolaan unit produksi di SMK berangkat dari teori dan konsep tentang manajemen serta konsep unit produksi.

Manajemen dalam penyelenggaraan pendidikan memiliki fungsi sangat penting dalam meningkatkan mutu pendidikan. Stoner, et. al (1995: p. 10) memberikan definisi, "Management is the process of planning, organizing, actuating, and controlling the effort of organization members and using all other organizational recources to achieve stted organizational goals. Definisi mengandung maksud bahwa ada aktivitas yang berbeda dalam melaksanakan proses manajemen. Pertama adalah aktivitas yang dilakukan untuk mencapai tujuan yang telah ditetapkan. Kedua aktivitas itu dilakukan oleh orang-orang yang dibantu oleh sumber-sumber daya lain, sumber daya yang ada difokuskan dalam fungsi manajemen yang sangat fundamental, yaitu fungsi planning, organizing, actuating, dan controlling sehingga tujuan organisasi dapat tercapai.

Manajemen merupakan proses mencapai tujuan. Hal ini sejalan dengan pendapat Bush \& Coleman (2000: p. 4), "Management is a continuous process through which members of organization seek to co-ordinate their activities and utilize their resources in order to fulfil the various tasks of organization as efficiently as possible. Manajemen merupakan proses berkelanjutan yang di dalamnya terdiri dari anggota-anggota organisasi yang mengkoordinasikan kegiatan-kegiatan dan menggunakan sumber daya mereka untuk menyelesaikan berbagai tugas organisasi seefisien mungkin

Manajemen merupakan suatu usaha mengkoordinasikan dan pengawasan dalam suatu kegiatan sehingga tujuannya dapat tercapai dengan baik secara efektif dan efisien seperti ditegaskan oleh Robbins dan Coulter, (2014: p. 33): "Managemen involves coordinating and overseeing the work activities of other so their activities are completed efficiently and effectively." Suatu kegiatan atau usaha yang dilakukan dengan manajemen yang baik, dengan koordinasi dan pengawasan akan menghasilkan sesuatu sesuai dengan tujuan.

Ruang lingkup atau bidang garapan manajemen pendidikan sebagai proses atau disebutjuga sebagai fungsi manajemen menurut Usman (2014: p. 19) adalah: perencanaan, pengorganisasian, pengarahan (motivasi, kepemimpinan, kekuasaan, pengambilan keputusan, komunikasi, koordinasi, negosiasi, manajemen konflik, perubahan organisasi, keterampilan interpersonal, membangun kepercayaan, penilaian kinerja, dan kepuasan kerja), dan pengendalian meliputi pemantauan (monitoring), penilaian dan pelaporan. Monitoring dan evaluasi sering disingkat ME atau Monev.

Perencanaan menurut Usman (2014: p. 77) merupakan sejumlah kegiatan yang akan dilakukan di masa yang akan datang untuk mencapai tujuan yang mengandung unsurunsur (1) sejumlah kegiatan yang ditetapkan sebelumnya, (2) adanya proses, (3) hasil yang ingin dicapai, dan (4) menyangkut masa depan dalam waktu tertentu. Kinichi dan Williams (2008: p. 12) mendefinisikan, "Planning is defined as setting goals and deciding how to achieve them." Perencanaan adalah seperangkat tujuan dan pertimbangan-pertimbangan tetang cara mencapai tujuan yang telah ditetapkan.

Perencanaan menurut Usman (2014: p. 77) adalah kegiatan yang akan dilaksanakan. Perencanaan adalah pengambilan keputusan. Proses perencanaan tidak dapat terlepas dari beberapa unsur diantaranya unsur pelaksanaan dan pengawasan termasuk pemantauan, penilaian, dan pelaporan. Proses merupakan hubungan tiga kegiatan yang berurutan, yaitu menilai situasi dan kondisi saat ini, 
merumuskan dan menetapkan situasi dan kondisi yang diinginkan (yang akan datang), dan menentukan apa saja yang perlu dilakukan untuk mencapai keadaan yang diinginkan. Zajda dan Gamage (2009: pp. 105-106) mengemukakan pentingnya perencanaan sebagai proses pengambilan keputusan yang melibatkan stakeholders seperti dijelaskan sebagai berikut.

The specific reasons for the significance of planning are as follows: How to provide for the effective participation of the relevant stake-holders categories of a school community in educational decision-making? How to make the curriculum more relevant to the changing environment in meeting the respective society's need?

Berdasarkan pendapat-pendapat di atas disimpulkan bahwa perencanaan adalah kegiatan yang akan dilakukan di masa yang akan datang untuk mencapai tujuan. Perencanaan tidak dapat dilepaskan dari unsur pelaksanaan dan pengawasan termasuk pemantauan, penilaian, dan pelaporan.

Pengorganisasian mengandung makna sebagai kesatuan yang memungkinkan masyarakat mencapai suatu tujuan yang tidak dapat dicapai individu secara perorangan (Gibson, Ivancevich dan Donnelly, 1996: p. 6). Pengertian ini mencirikan perilaku organisasi adalah mencapai tujuan organisasi yang disetujui bersama. Organisasi diartikan sebagai kesatuan sosial yang dikoordinasikan secara sadar, terdiri dari 2 orang atau lebih yang berfungsi relatif terus menerus untuk mencapi tujuan atau seperangkat tujuan (Stoner, et. al, 1995: p. 6).

Pengorganisasian menurut Handoko (2003) dalam Usman (2014: p. 170), adalah: (1) penentuan sumber daya dan kegiatan yang dibutuhkan untuk mencapai tujuan organisasi, (2) proses perancangan dan pengembangan suatu organisasi yang akan dapat membawa hal-hal tersebut ke arah tujuan, (3) penugasan tanggung jawab tertentu, (4) pendelegasian wewenang yang diperlukan kepada individuindividu untuk melaksanakan tugastugasnya. Ditambahkan pula oleh Handoko, pengorganisasian adalah pengaturan kerja bersama sumber daya keuangan, fisik, dan manusia dalam organisasi. Pengorganisasian merupakan penyusunan struktur organisasi yang sesuai dengan tujuan organisasi, sumber daya yang dimilikinya, dan lingkungan yang melingkupinya.

Pelaksanaan merupakan fungsi manajemen yang terpenting dan paling dominan dalam proses manajemen. Fungsi ini baru diterapkan setelah rencana, organisasi dan karyawan ada. Jika fungsi ini diterapkan maka proses manajemen dalam merealisasi tujuan dimulai. Pelaksanaan adalah membuat semua anggota kelompok, agar mau bekerja sama dan bekerja secara ikhlas dan bergairah untuk mencapai tujuan sesuai dengan perencanaan dan usahausaha pengorganisasian.

Handoko (2003: p. 25) menjelaskan bahwa fungsi pelaksanaan adalah menjadikan para karyawan melakukan apa yang diinginkan dan harus mereka lakukan. Fungsi ini akan berjalan dengan baik apabila didukung dengan kualitas, gaya dan kekuasaan pemimpin dan kegiatan-kegiatan kepemimpinan yang memadai seperti komunikasi, motivasi dan disiplin. Bagaimana menggerakkan karyawan, pegawai atau anggota organisasi selalu diawali dengan kegiatan memberikan motivasi agar bersedia melakukan kegiatan atau pekerjaan yang sesuai dengan arah dan tujuan yang telah ditetapkan dalam perencanaan. Karyawan yang melihat sumber motivasi dari dalam dirinya cenderung berorietasi pada kemajuan, sedangkan karyawan yang melihat sumber motivasi dari luar cenderung berorientasi pada antisipasi. Hal ini dikemukakan oleh Meyer, et. al, (2004: pp. 991-1007) berikut:

Employees who view their behavior as more internally driven (intrinsic, identified, and integrated regulation) perceive themselves as working toward the accomplishment of ideals (promotion focus). Those who view their behavior as more externally driven (external or introjected regulation) perceive themselves as working toward the fulfillment of obligations (prevention focus).

Koordinasi selalu dibutuhkan dalam setiap organisasi agar berfungsi dengan baik. Tanpa adanya koordinasi setiap pekerjaan dari individu karyawan maka tujuan perusahaan 
tidak akan tercapai. Hasibuan (2014: p. 85) berpendapat bahwa: "Koordinasi adalah kegiatan mengarahkan, mengintegrasikan, dan mengkoordinasikan unsur -unsur manajemen dan pekerjaan-pekerjaan para bawahan dalam mencapai tujuan organisasi". Koordinasi adalah proses pengintegrasian tujuan-tujuan dan kegiatan-kegiatan pada satuan-satuan yang terpisah (departemen-departemen atau bidangbidang fungsional) pada suatu organisasi untuk mencapai tujuan secara efisien dan efektif (Handoko 2003 : p. 195).

Komunikasi di dalam suatu organisasi menurut Muhammad (2014: p. 1) penting karena komunikasi yang baik maka suatu organisasi dapat berjalan lancar dan berhasil. Sebaliknya tidak adanya komunikasi akan menimbulkan konflik antara anggota organisasi dan dampaknya mengganggu komunikasi dalam kelompok tersebut. Tujuan dan manfaat komunikasi menurut Usman (2014: p. 346) adalah sarana untuk: (1) meningkatkan kemampuan manajerial dan hubungan sosial, (2) menyampaikan dan atau menerima informasi, (3) menyampaikan dan menjawab pertanyaan, (4) mengubah perilaku (pola pikir, perasaan, dan tindakan) melalui perencanaan, pengorganisasian, pengarahan, motivasi, koordinasi, dan pengawasan.

Pengawasan menurut Fatah (2004: p. 101) merupakan proses untuk melihat sejauh mana hasil yang diharapkan tercapai. Pengawasan dilakukan melalui tiga tahap yaitu: (1) menetapkan standar pelaksanaan, (2) pengukuran pelaksanaan pekerjaan dibandingkan dengan standar, dan (3) menentukan kesenjangan antara pelaksanaan dengan rencana. Jadi kegiatan ini bertujuan untuk mengetahui apakah strategi, metode dan teknik yang telah ditetapkan dalam perencanaan sudah cukup cocok dengan langkah penyampaian tujuan dan dengan resiko yang sekecil-kecilnya.

Manfaat pengawasan menurut Mockler (dalam Handoko, 2003: p. 366) yaitu upaya mendeteksi perubahan-perubahan agar mampu memanfaatkan perubaha dengan baik, mendeteksi kesalahan-kesalahan dan memastikan dilaksanakannya pelimpahan tugas. Jadi pengawasan ini bertujuan untuk mengetahui kesalahan sedini mungkin, mendeteksi perubahan dan peluang, serta memastikan pendelegasian wewenang dilaksanakan dengan baik.

Pendidikan di SMK menurut kurikulum tahun 2004 bertujuan untuk mencetak tenaga kerja terampil. Pendidikan di SMK menggunakan pendekatan sebagai berikut: (a) pendekatan akademik, (b) pendekatan kecakapan hidup (life skills), (c) pendekatan kurikulum berbasis kompetensi (competencybased curriculum), (d) pendekatan kurikulum berbasis luas dan mendasar (broad-based curriculum), (e) pendekatan kurikulum berbasis produksi (production-based curriculum).

Pendekatan Kecakapan Hidup (life skills) mendekatkan peserta didik dengan dunia nyatanya di mana ia hidup dan bermasyarakat. Oleh karena itu, agar peserta didik dapat mengenal dengan baik dunianya dan dapathidup wajar di masyarakat, perlu dibekali kecakapan hidup (life skills). Kecakapan hidup meliputi: (a) kecakapan personal (personal skills) (b) kecakapan sosial (social skills), (c) kecakapan akademik (academic skills), dan (d) kecakapan vokasional (vocational skills). Pendekatan Kurikulum Berbasis Kompetensi (competencybased curriculum) diartikan sebagai rancangan pendidikan dan pelatihan yang dikembangkan berdasarkan standar kompetensi yang berlaku di tempat kerja (Sudira, 2006: p. 8).

Pendekatan Kurikulum Berbasis Produksi (production based curriculum) adalah kegiatan pendidikan dan pelatihan yang menyatu pada proses produksi atau menggunakan proses produksi sebagai media pembelajaran. Pendekatan ini dilakukan dengan tujuan terutama untuk memperkenalkan peserta didik dengan iklim kerja yang nyata. Pelaksanaan pembelajaran bisa dilakukan dengan cara antara lain sebagai berikut: pembelajaran di dunia industri. Peserta didik mendapat pelatihan dan pengalaman nyata melalui keterlibatan langsung dalam proses produksi di dunia industri sebagai media pendidikan; pembelajaran di sekolah. Peserta didik dilibatkan dalam proses produksi di unit produksi sekolah. Pembelajaran di sekolah, peserta didik berpraktik di ruang praktikum yang menerapkan mekanisme produksi, sehingga tercipta suasana kerja seperti di 
industri. Pelatihan harus menghasilkan produk yang memenuhi standar industri dan layak jual (Sudira, 2006: p. 9).

Pendekatan pembelajaran berbasis kompetensi harus menganut prinsip pembelajaran tuntas (mastery learning) untuk dapat menguasai sikap (attitude), ilmu pengetahuan (knowledge), dan keterampilan (skills) agar dapat bekerja sesuai dengan profesinya seperti yang dituntut oleh suatu kompetensi. Untuk dapat belajar secara tuntas, perlu dikembangkan prinsip pembelajaran (1) Learning by doing (belajar melalui aktivitas/ kegiatan nyata, yang memberikan pengalaman belajar bermakna) yang dikembangkan menjadi pembelajaran berbasis produksi, (2) Individualized learning (pembelajaran dengan memperhatikan keunikan setiap individu) yang dilaksanakan dengan sistem modular. Pelaksanaan pembelajaran dengan pendekatan tersebut dapat dilakukan melalui dua jalur alternatif (1) jalur kelas industri/employee: peserta didik belajar di sekolah dan berlatih di industri, (2) jalur kelas wiraswasta/mandiri/ self employed: peserta didik belajar dan berlatih berwiraswasta di sekolah dan berusaha secara mandiri. Beban belajar SMK/MAK meliputi kegiatan pembelajaran tatap muka, praktik di sekolah dan kegiatan kerja praktik di dunia usaha/industri ekuivalen dengan 36 jam pelajaran per minggu. Pelaksanaan pendidikan menengah kejuruan akan mencapai sasaran jika menerapkan prinsip-prinsip bahwa pendidikan kejuruan efisien jika lingkungan dimana peserta didik dilatih merupakan replika lingkungan dimana nanti bekerja (Sudira, 2006: p. 11).

Alptekin. S, dalam Proceedings of the 2001 American Society for Engineering Education Annual Conference \& Exposition The, menyatakan sebagai berikut. "Teaching Factory will have dual purposes. One is to enable students to develop small-scale industrial products or consumer goods. The second purpose is to provide tools for the planning and controlling of the required manufacturing operations for building small quantities of the verified designs".

Fungsi dari unit produksi dimaksudkan supaya siswa dapat dilatih untuk berwirausaha dalam rangka mengembangkan usaha kecil yang dapat menerima pesanan dari pihak luar, sehingga dengan kebiasaan yang dilakukan di unit produksi maka nantinya jiwa kewirausahaan siswa akan dapat terbangun dengan baik. Setelah lulus siswa akan dapat dengan menudah mengaplikasikan ilmu yang didapat dari unit produksi di industri maupun untuk berwirausaha sendiri. Ketika mereka memesuki dunia industri sudah tidak bingung lagi tentang apa yang arus dikerjakan di di industri karena unit produksi yang ada di sekolah merupakan mini indstri yang ada di sekolah.

Unit Produksi merupakan suatu sarana pembelajaran berwirausaha bagi siswa dan guru serta memberi dukungan operasional sekolah. Unit produksi merupakan suatu program usaha kegiatan peningkatan mutu sekolah yang pada dasarnya dirancang sabagai sarana peningkatan kemampuan dan ketrampilan sumber daya manusia. Sumber daya manusia yang dimaksud adalah pengelola unit produksi dan siswa. Selain sebagai peningkatan skualitas sumber daya manusia yang ada unit produksi juga berguna sebagai pengoptimalisasaikan fasilitas yang ada di sekolah sehingga alat-atat yang ada disela kegiatan pembelajaran dapat terpakai dengan optimal.

UPJ dimaksudkan sebagai sarana belajar dan latihan keterampilan. Manajemen training vokasi di UPJ dapat lebih sukses dengan mempertimbangkan kriteria yang relevan dengan pasar tenaga kerja, akses bagi traineer, kualitas pengiriman, standardisasi, dimasukkannya soft skill, dan pendanaan untuk sistem ini aman dan tidak terputus (Nasir, 2012: p. 10). Manajemen unit produki mencakup pelaksanaan fungsi-fungsi manajemen dalam kegiatan unit produksi mulai dari perencanaan, pengorganisasian, pelaksanaan dan pengawasan atau evaluasi.

Penelitian Tawardjono (2011) tentang model unit produksi SMK di Daerah Istimewa Yogyakarta dengan mengambil Studi Kasus di SMKN 2 Pengasih Kulonprogo Jurusan Teknik Otomotif, memperlihatkan bahwa: (1) Perencanaan, pelaksanaan, dan pengawasan unit produksi SMK bidang Otomotif di DIY belum dilaksanakan secara optimal; (2) 
Perkembangan unit produksi masih berjalan di tempat, (3) Model unit produksi SMK bidang Otomotif yang ditawarkan: (a) membuat desain unit produksi sekolah; (b) merencanakan program, yang terdiri: membuat visi, misi, dan tujuan, menetapkan kegiatan, menetapkan hasil yang akan dicapai dan kegiatan pengawasan yang akan dilakukan; (c) melaksanakan program, yang terdiri: mempersiapkan sarana dan prasarana serta bahan dan peralatan, merekrut sumber daya manusia; membuat struktur organisasi; pendelegasian tugas dan wewenang; menentukan mata pelajaran prasyarat; mengatur jadwal waktu pelaksanaan; mengatur penempatan dan tugas siswa; melakukan promosi dan pemasaran; dan melakukan kerja sama dengan mitra dunia usaha dan dunia industri; (d) mengawasi program, yang terdiri atas: pengawasan pada saat dimulainya perencanaan, pengawasan saat kegiatan pelaksanaan program kerja berlangsung, dan pengawasan setelah akhir program; (e) menentukan mata pelajaran prasyarat, dan (f) menghargai personil yang terlibat.

Studi pendahuluan melalui wawancara dan observasi di SMKN 2 Pengasih memperlihatkan sejumlah permasalahan dalam pengelolaan UPJ rumpun bangunan. Idealnya, UPJ Jurusan Teknik Konstruksi Kayu dikelola dengan menerapkan prinsip-prinsip manajemen yang baik. Pada kenyataannya, pengelola UPJ tidak memiliki suatu perencanaan tertulis dan dapat dijadikan pedoman dalam menjalankan UPJ. Perencanaan dapat dikatakan hanya didasarkan pada pembicaraan secara informal di antara para pengelola UPJ. Perencanaan yang tidak optimal atau bahkan tanpa perencanaan menimbulkan konsekuensi yaitu pelaksanaan UPJ yang belum sepenuhnya berjalan dengan baik meskipun UPJ di SMKN 2 Pengasih ini sudah dipandang yang paling baik dibandingkan UPJ rumpun bangunan pada SMK-SMK di DIY. UPJ seharusnya juga difungsikan untuk belajar praktik berwirausaha, pada kenyataannya masih terbatas pada bengkel kerja dan tidak lebih sebagai sarana praktik bagi siswa.

Pelaksanaan UPJ berdasarkan hasil observasi berjalan sesuai dengan pesanan yang ada dari pihak luar dan juga membuat barang-barang yang dibutuhan oleh sekolah sebagai cadangan kebutuhan seperti meja dan kursi, pelaksanaan unit produksi kebanyakan dilaksanakan oleh para tukang yang dimiliki oleh unit produksi tersebut. Pelaksanaan unit produksi di SMK perlu adanya koordninasi yang baik antara pengelola dan tukang maupun dengan siswa sebagai tempat mereka berlatih di unit produksi tidak semua diserahkan kepada tukang yang ada. Pelaksanaan UPJ di SMK ini belum menerapkan evaluasi secara rutin atau berkala serta terukur. Belum adanya evaluasi yang rutin dan terukur menjadikan pengelola ataupun pihak sekolah hanya melihat kemajuan UPJ dari membandingkan UPJ yang ada di sekolah lain atau melihat berfungsinya UPJ sebagai sarana praktik bagi siswanya.

Pengelolaan unit produksi SMK Negeri rumpun bangunan di Daerah Istimewa Yogyakarta, khususnya di SMKN 2 Pengasih Kulonprogo penting untuk diteliti guna mendapatkan gambaran tentang perencanaan, pengorganisasian, pelaksanaan, dan evaluasi sehingga dapat menghasilkan sejumlah rekomendasi sebagai upaya peningkatan mutu pendidikan di unit produksi rumpun bangunan. Rumpun bangunan perlu dikelola sebaik mungkin agar tetap menarik minat siswa untuk mempelajari program keahlian teknik bangunan.

\section{METODE PENELITIAN}

\section{Jenis Penelitian}

Penelitian ini termasuk pendekatan penelitian kualitatif dengan jenis studi kasus sehingga nantinya dapat memberikan gambaran tentang fenomena yang diteliti.

\section{Waktu dan Tempat Penelitian}

Waktu penelitian dilakukan selama 5 bulan terhitung dari bulan Desember 2013 sampai dengan bulan April 2014. Penelitian yang dilakukan adalah di unit produksi Jurusan (UPJ) Teknik Konstruksi Kayu di SMK Negeri 2 Pengasih Kulonprogo, Daerah Istimewa Yogyakarta.

\section{Subjek Penelitian}

Subjek penelitian ini adalah pengelola unit produksi Jurusan Teknik Konstruksi Kayu 
SMKN 2 Pengasih, yang meliputi: Ketua Unit Produksi Jurusan Teknik Konstruksi Kayu, Ketua Unit produksi sekolah, dan Kepala Bengkel Jurusan Teknik Konstruksi Kayu. Unit produksi yang diteliti adalah unit produksi di SMKN 2 Pengasih. Ketiga orang ini sekaligus sebagai informan karena secara struktural memiliki otoritas dan wewenang yang kuat dalam mengelola unit produksi di Jurusan Teknik Konstruksi Kayu, mulai dari perencanaan, pengorganisasian, pelaksanaan dan pengawasan

\section{Teknik dan Instrumen Pengumpulan Data}

Teknik yang digunakan dalam pengumpulan data adalah dengan wawancara, observasi dan dokumen yang ada di unit produksi

\section{Keabsahan Data}

Penelitan kualitatif data yang telah berhasil digali, dikumpulkan dan dicatat serta diusahakan kemantapan dan kebenarannya. Peneliti memilih dan menentukan cara-cara yang tepat untuk mengembangkan validitas data yang diperoleh. Dalam penelitian ini, validitas data yang digunakaan oleh peneliti menggunakan teknik triangulasi dan diskusi teman sejawat. Triangulasi yang digunakan yaitu model triangulasi metode pengumpulan data. Caranya, data yang sudah didapat dari pengamatan ditanyakan oleh peneliti kepada informan penelitian. Data hasil wawancara kepada satu informan ditanyakan kembali kepada informan yang lainnya. Informasi yang didapat dari informan juga dicroscek melalui observasi lapangan.Triangulasi juga dilakukan dengan menguji pemahaman peneliti dengan pemahaman informan tentang hal-hal yang diinformasikan informan kepada peneliti. Hal ini dilakukan untuk menghindarkan adanya pemahaman yang berbeda. Cara ini dilakukan setelah wawancara atau observasi ketika semua informasi telah dipresentasikan dalam draft laporan.

\section{Teknik Analisis Data}

Selama proses pengumpulan data, peneliti juga memilah-milah data berdasarkan permasalahan yang diteliti sehingga dapat dikelompokan menjadi empat kelompok data yaitu data tentang perencanaan, pengorganisasian, pelaksanaan, dan data tentang pengawasan unit produksi Jurusan Teknik Konstruksi Kayu SMKN 2 Pengasih. Pemilahan data ini menjadikan pengumpulan data lebih bermakna. Pemilahan ini menjadikan peneliti mudah mengetahui data yang belum lengkap atau masih kurang sehingga harus dilakukan pengambilan data kembali baik melalui wawancara ataupun observasi. Pada penelitian ini, wawancara kepada setiap informan dilakukan masing-masing tiga kali.

Peneliti membuat catatan lapangan yang berisikan deskripsi singkat mengenai apa yang dilihat, didengar atau apa yang dirasakan oleh subjek penelitian. Catatan ini memudahkan peneliti untuk mengetahui sesuatu yang belum atau harus ditanyakan untuk melengkapi data.

Semua data yang terkumpul, baik melalui wawancara ataupun pengamatan direduksi. Data yang dipandang kurang penting atau kurang relevan disisihkan sehingga hanya data-data penting yang kemudian dikaji lebih lanjut agar analisis lebih mendalam dan lebih tajam. Data yang sudah direduksi dan dianalisis kemudian disusun sedemikian rupa mengikuti sistematika penulisan laporan penelitian yang sudah dirancang.

Analisis selanjutnya yaitu penyajian data. Pada tahap ini, data-data yang telah dianalisis kemudian dinarasikan secara deskriptif argumentatif untuk menjawab permasalahan yang diteliti. Oleh karena itu, dalam menyajikan data hasil penelitian ini, peneliti lebih banyak memaknai data temuan dalam bentuk kata-kata komunikatif sesuai dengan fokus penelitian yang diungkap. Ketika data dipandang kurang, peneliti kembali menemui subjek penelitian untuk melakukan wawancara dan melakukan observasi.

Selama proses penyusunan laporan hasil penelitian, sering dilakukan verifikasi terhadap data yang hendak dituliskan dalam laporan dengan cara membandingkan data hasil dari satu sumber dengan data dari sumber lainnya. Cara ini dijalankan sambil mengungkap makna dari data yang dikumpulkan. Verifikasi juga dilakukan dengan melihat kembali pada reduksi data maupun display data, sehingga kesimpulan yang diambil tidak menyimpang dari data yang dianalisis. 


\section{HASIL PENELITIAN DAN PEMBAHASAN}

Perencanaan sebagaimana dijelaskan YT tidak selalu terjadi setiap semester. Pembahasan tentang rencana hanya dilakukan setelah jelas ada kegiatan UPJ yang paralel dengan pelajaran praktik di bengkel. Misalnya, UPJ mendapat pesanan kusen kayu yang pelaksanaannya berbarengan dengan pelajaran praktik membuat kusen maka kegiatan UPJ dalam membuat kusen kayu sekaligus melibatkan siswa yang sedang praktik membuat kusen. Dalam hal ini, UPJ Jurusan Teknik Konstruksi Kayu dapat menjadi sarana praktik bagi siswa seperti dikemukakan AS berikut. "Kalau terutama yang melibatkan siswa biasanya dari awal sudah direncanakan biasanya awal tahun kelas 2 tapi itu yang kurikulum lama kalau kurikulum baru saya lihat tidak ya, kalau awal dulu kan kurikulum lama itu kelas 2 awal itu menggunakan mesin tetap dalam membuat kusen itu biasanya kalau pas ada itu bisanya dimasukkan untuk pekerjaan UPJ, agar siswa itu betul-betul membuat benda yang sesungguhnya tidak hanya model atau benda kerja yang di buat sekala". (wawancara tanggal 16 januari 2014). (W.S.A.1.6). Pada kenyataannya hal tersebut sangat jarang terjadi. UPJ Jurusan Teknik Konstruksi Kayu dan kegiatan praktik siswa sering berjalan sendiri-sendiri meskipun berada dalam satu ruang bengkel yang sama. Observasi di ruang produksi memperlihatkan siswa mengadakan praktik membuat miniatur di bengkel sementara sebanyak 4 tukang kayu sedang mengerjakan produksi dari pesanan. Beberapa kali terjadi komunikasi antara siswa dengan tukang terkait dengan penggunaan alat. Perencanaan UPJ Jurusan Teknik Konstruksi Kayu dapat dikatakan belum dilakukan karena ketentuan pelaksanaan kegiatan UPJ Jurusan Teknik Konstruksi Kayu sepenuhnya bergantung pada kepala bengkel. Fakta ini dikemukakan oleh AS (Ketua UPJ Teknik Konstruksi Kayu) sebagai berikut: "Kalau perencanaan itu memang belum ada, kerena saya mengikuti perintah dari bengkel misalnya bengkel menginginkan seperti ini ya saya ikut saja, kelihatanya input pengembangann itu dari bengkel". (wawancara tanggal 16 januari 2014) (W.S.A.1.3).
Triangulasi terhadap data di atas dilakukan dengan mempelajari dokumen tertulis dari sekolah. Penelusuran dokumen sekolah meliputi profil sekolah, kurikulum, program kerja sekolah, silabus, serta dokumen tentang laporan UPJ Jurusan Teknik Konstruksi Kayu membuktikan bahwa tidak ada data yang menyebutkan adanya perencanaan secara tertulis. Fakta ini menegaskan perencanaan memang tidak dilakukan. UPJ Jurusan Teknik Konstruksi Kayu sebagai sarana pembelajaran sesuai dengan kompetensi Jurusan Teknik Konstruksi Kayu sudah memiliki perencanaan yang tercakup dalam kurikulum atau silabus pembelajarannya. Namun, UPJ Jurusan Teknik Konstruksi Kayu sebagai unit produksi yang dapat menghasilkan keuntungan ekonomi tidak memiliki perencanaan yang jelas. Hal ini tidak sesuai dengan konsep perencanaan sebagai sejumlah kegiatan yang akan dilakukan dimasa yang akan datang untuk mencapai tujuan yang mengandung unsur-unsur (1) sejumlah kegiatan yang ditetapkan sebelumnya, (2) adanya proses, (3) hasil yang ingin dicapai, dan (4) menyangkut masa depan dalam waktu tertentu (Usman, 2014: p. 77). Ketidak sesuaian ini tampak dari perencanaan UPJ Jurusan Teknik Konstruksi Kayu tidak memasang target hasil apapun terkait dengan UPJ sebagai unit yang menghasilkan keuntungan ekonomis dan latihan berwirausaha.

Fungsi perencanaan yang tidak berjalan dengan baik memperlihatkan adanya sejumlah kendala dalam menyusun perencanaan. Beberapa kendala yang diungkap yaitu dokumentasi yang lemah dan pengambilan keputusan secara informal. Pembicaraan mengenai rencana tersebut dilakukan secara informal dan tidak terdokumentasikan. "Pernah juga cuma sebatas informal dalam arti bukan dalam forum rapat atau forum resmi sehingga mungkin sehingga dokumentasi dari pembicaraan tadi tidak tersimpan dengan baik ketika mau mengontrol ini kan kemudian kalau bahasa jawanya "kelangan enggok" jadi intinya perlu didokumentasikan perencanaan itu secara lebih rapi lagi termasuk usulan-usulan atau masukan itu nanti kemudian ditindak lanjuti, mestinya begitu". (wawancara dengan MJ, tanggal 16 januari 2014). (W.S.M.1.15). 
Pembicaraan informal terjadi karena tidak ada pertemuan rutin para pengelola UPJ. Pertemuan rutin tidak dilakukan karena komunikasi tidak harus dilakukan dalam forum rapat, tetapi dapat disampaikan setiap saat mereka bertemu. Akibatnya, hasil pembicaraan yang telah disepakati tidak didokumentasikan atau tidak disusun dalam bentuk perencanaan yang tertulis. Kendala berupa tidak adanya rapat rutin dan dokumentasi yang baik bukan karena pengelola tidak memahami pentingnya perencanaan UPJ. Para pengelola menyadari pentingnya perencanaan unit produksi sebagai fungsi kontrol sehingga unit produksi bekerja dengan suatu desain dan arahan yang jelas dan terukur. Hal ini ditegaskan oleh MJ sebagai berikut. "Perencanaan berfungsi untuk mengontrol sehingga apa-apa yang dilakukan oleh unit produksi ini memang by design tidak kemudian reaktif atau apa yang ada kemudian dikerjakan itu tidak kegiatannya memang ada target-target yang dicanangkan nah target-target itulah yang dituangkan dalam perencanaan kemudian langkah-langkah dilapangan ya harapanya kalaupun itu tidak terpenuhi semua itu mendekati apa yang direncanakan". (wawancara tanggal 16 januari 2014). (W.S.M.1.6).

Triangulasi data terhadap data perencanaan dilakukan dengan membandingkan keterangan dari Ketua UPJ sekolah dengan Ketua UPJ Jurusan Teknik Konstruksi Kayu. Tampak ada keterangan yang tidak konsisten, di satu sisi perencanaan penting agar kegiatan UPJ terarah, tetapi di sisi lain dikatakan hanya perencanaan evaluasi yang ada. Pengelolaan belum didasarkan pada perencanaan yang bersifat strategis, tetapi secara operasional telah ada perencanaan operasional kerja yang menjadi pedoman bagi para tukang dalam menjalankan pekerjaan di bengkel. Menurut Fattah (2004: p. 58), perencanaan operasional memusatkan perhatian pada apa yang akan dilakukan di lapangan. Secara konsep, perencanaan operasional merupakan terjemahan dari perencanaan strategis. Temuan penelitian memperlihatka hal bertentangan yaitu perencanaan operasional merupakan respon terhadap pesanan yang masuk ke bengkel. Tidak adanya perencanaan strategik terjadi karena para pengelola lebih berorientasi pada fungsi UPJ sebagai sarana pembelajaran, bukan sebuah unit produksi yang berorientasi profit.

Pihak-pihak yang seharusnya berperan dalam merencanakan UPJ Jurusan Teknik Konstruksi Kayu hanya 5 orang yaitu ketua program studi, kepala bengkel, ketua unit produksi, wakil kepala sekolah bidang sarana prasarana dan bendahara sekolah. Kelima orang tersebut seharusnya dapat berkoordinasi dengan mudah untuk membuat suatu perencanaan. Pihak-pihak yang seharusnya terlibat dalam perencanaan tampak pada proses pengambilan keputusan apabila unit produksi mendapatkan banyak pesanan dari luar sekolah. AS mengemukakan sebagai berikut: "Kalau yang terlibat ya kaprodi $\mathrm{P}$ MJ, kabeng dan saya sendiri juga sering mengundang depan karena jurusannya kayu dengan Pak Marsudi sebagai Waka Sekolah dan Pak Sumari sebagai bendahara terutama kalau berhubungan dengan biaya kami minta pertimbangan Pak Sumari kalau kita dapat job agak lumayan ternyata kas UPJ kok tidak mampu kita rembugan Pak Sumari gimana baiknya bisa diterima atau tidak istilahnya kalau Pak Sumari iya, kan kalau beliau bilang iya beliau sudah tahu kalau UPJ harus bon uang dulu ke kas sekolah bisa". (wawancara tanggal 16 januari 2014). (W.S.A.1.8).

Kenyataannya, para pihak tersebut tidak mengambil peran dalam perencanaan. Wakil kepala sekolah bidang sarana prasarana dan bendahara sekolah hanya terlibat ketika UPJ menerima pesanan dalam jumlah besar sehingga harus meminjam uang kas sekolah. Artinya, kepala bengkel, dan ketua UPJ hanya melibatkan wakil kepala sekolah dan bendahara sekolah secara terbatas, yaitu hanya ketika ada pesanan dalam jumlah besar. Perencanaan yang tidak disusun secara tertulis dan tidak adanya pengambilan keputusan oleh semua pihak ini bertentangan dengan pendapat Zajda dan Gamage (2009: pp. 105-106) yang mengemukakan pentingnya perencanaan sebagai proses pengambilan keputusan yang melibatkan stakeholders. Minimnya keterlibatan stakeholders terjadi karena semua pihak berpedoman pada rutinitas UPJ Jurusan Teknik Konstruksi Kayu yang sepenuhnya 
dapat diserahkan kepada kepala UPJ sendiri atau bahkan kepada kepala bengkel.

Perencanaan di masing-masing UPJ Jurusan Teknik Konstruksi Kayu memang diserahkan kepada jurusan Teknik Konstruksi Kayu. Pengelola UPJ bukan orang profesional, hanya merupakan pekerjaan tambahan seorang guru sehingga teaching factory belum dikelola secara profesional. Keterlibatan ketua UPJ dan bengkel Jurusan Teknik Konstruksi Kayu dalam membuat perencanaan sekedar menyampaikan secara informal di luar rapat dengan ketua program ataupun pada saat rapat dengan kepala sekolah dan guru-guru yang lainnya.

Fungsi pengorganisasian dalam manajemen merupakan fungsi lanjutan dari perencanaan. Pengorganisasian mencakup pembagian tugas, pendelegasian tugas dan wewenang, serta koordinasi. Pembagian tugas dalam pengelolaan UPJ ditunjukkan dengan adanya struktur organisasi kerja seperti ketua program studi, ketua UPJ, kepala bengkel, dan toolman (pegawai pemeliharaan alat-alat) serta tukang. Tugas sehari-hari di bengkel UPJ di bawah tanggung jawab kepala bengkel. Kepala bengkel mendapat wewenang dalam menghitung kebutuhan bahan dan alat-alat. Tugas kepala bengkel sehari-hari dibantu oleh toolman. Pendelegasian tugas di unit produksi sudah berjalan dengan pembagian kerja sebagai berikut: Ketua UPJ menerima pesanan atau order dari konsumen. Ketua UPJ yang langsung menghitung harga, model atau desain, bahan produksi dan lama pengerjaan. Kriteria order yang sudah masuk dan ditetapkan desain, bahan dan lama pengerjaan kemudian diserahkan oleh ketua UPJ kepada tukang. Ketua UPJ juga meminta kepala bengkel untuk mengecek ketersediaan bahan untuk memenuhi order.

UPJ berfungsi sebagai unit produksi untuk menghasilkan suatu produk yang dibutuhkan masyarakat juga berfungsi sebagai sarana praktik siswa. Pendelegasian pekerjaan kepada tukang disesuaikan dengan jumlah order, desain dan lama pengerjaan. Tukang yang setiap hari ada di bengkel ada 6 orang. Semua tukang kayu berstatus tenaga harian, artinya mereka akan mendapatkan upah apabila mereka masuk kerja. Di luar UPJ Jurusan Teknik Konstruksi Kayu, para tukang bebas bekerja di tempat lain. Koordinasi dalam pengelolaan unit produksi dilakukan oleh kepala unit produksi. Koordinasi yang pasti dilakukan adalah dengan para tukang terkait dengan pekerjaan untuk melayani pesanan. Apabila membutuhkan tenaga ekstra, ketua unit produksi mengajak guru-guru yang bisa untuk bersedia membantu.

Posisi sebagai tugas tambahan ini menunjukkan tugas pokok mereka sebagai guru lebih penting dan harus diutamakan untuk dijalankan lebih dulu. Hal ini dipandang cukup efektif karena UPJ yang merupakan sarana belajar dapat lebih optimal. Koordinasi dengan guru-guru yang akan menggunakan UPJ juga dapat lebih mudah dilakukan. Namun, para guru tidak memiliki cukup tenaga dan pikiran untuk mengembangkan UPJ Jurusan Teknik Konstruksi Kayu sebagai unit produksi yang berorientasi profit. Guru-guru yang diberi tugas sebagai pengelola UPJ tidak berani ambil resiko kehilangan banyak waktu untuk mengerjakan tugas pokoknya sebagai guru. Hal ini memperlihatkan bahwa UPJ Jurusan Teknik Konstruksi Kayu sebenarnya kurang memiliki sumber daya manusia yang secara penuh mengelola UPJ Jurusan Teknik Konstruksi Kayu. Temuan ini sejalan dengan penelitian Sudaryat (2013) yang menyimpulkan bahwa sikap mental sumber daya manusia terutama guru dalam memerankan dirinya (sebagai pengajar dan pelatih, perencana usaha, pelaksana usaha dan manajer usaha). Budaya kerja SMK belum selaras dengan budaya kerja di industri.

Terkait dengan pengorganisasian, kendala yang dihadapi menurut ketua UPJ sekolah adalah personalia, sarana dan peralatan yang kurang serta koordinasi di antara pengelola. Kendala dari aspek personalia yaitu ketersediaan tukang yang tidak selalu sama jumlahnya karena para tukang bukanlah pekerja tetap UPJ Jurusan Teknik Konstruksi Kayu. Akibatnya, ketika harus berkoordinasi dengan tukang untuk mengukur kemampuan memenuhi order sesuai jadwal agak kesulitan.

Kendala sarana dan alat tampak dari tidak ada tempat menyimpan sehingga ketika barang 
sudah jadi, maka pengelola harus menempatkan barang pesanan di tempat lain yang dapat ditempati sehingga penempatan barang kurang efektif. Bahan baku kayu yang ada juga sebatas stok bantuan dari sekolah sehingga ketika ada pesanan yang banyak harus beli bahan. Sebagian ruangan bengkel juga digunakan untuk meletakkan hasil pekerjaan sehingga ruangan bengkel menjadi lebih sempit. Realitas kondisi UPJ tersebut tidak sejalan dengan konsep pengorganisasian Handoko (2003) bahwa pengorganisasian harus merancang struktur formal untuk penggunaan yang paling efektif terhadap sumber daya keuangan, fisik, bahan baku, dan tenaga kerja organisasi. Hal ini terjadi karena ruang produksi dan ruang bengkel berada dalam satu gedung yang tidak ada batasannya. Selain itu, ketiadaan rencana produksi di luar produksi untuk pesanan juga menjadi alasan pengorganisasian di UPJ ini tidak membuat suatu rancangan penggunaan sumber daya keuangan, fisik, bahan baku, dan tenaga kerja organisasi.

Kendala koordinasi tampak pada tidak adanya koordinasi yang memadai antara UPJ Jurusan Teknik Konstruksi Kayu dengan UPJUPJ di masing-masing jurusan ataupun dengan UPJ sekolah. Koordinsi antara UPJ Jurusan Teknik Konstruksi Kayu dengan para guru juga masih kurang. Kegiatan koordinasi dengan guru baru terbatas pada persiapan untuk memenuhi order. Koordinasi dengan sekolah terkait dengan pesanan. Sangat jarang ada koordinasi dengan ketua UPJ sekolah, kecuali yang berkaitan dengan laporan keuangan setiap bulannya. Koordinasi dan pelaporan yang intensif baru sebatas masalah keuangan

Pengorganisasian UPJ Jurusan Teknik Konstruksi Kayu sebagai bagian dari pengorganisasian sekolah membutuhkan adanya pemahaman yang sama tentang tujuan organisasi sekolah, khususnya tujuan UPJ Jurusan Teknik Konstruksi Kayu. Hal ini sejalan dengan penjelasan Handoko (2003) dalam Usman (2014: p. 170) bahwa pengorganisasian juga mencakup penentuan sumber daya dan kegiatan yang dibutuhkan untuk mencapai tujuan organisasi. Penentuan alokasi sumber daya yang dibutuhkan untuk memajukan UPJ Jurusan Teknik Konstruksi Kayu hanya dapat dilakukan setelah adanya pemahaman tentang tujuan UPJ Jurusan Teknik Konstruksi Kayu itu sendiri.

Pelaksanaan unit produksi merupakan bagian dari fungsi manajemen UPJ Jurusan Teknik Konstruksi Kayu. Fungsi dalam pelaksanaan dijalankan oleh pengelola UPJ dengan cara menggerakkan pihak-pihak yang terlibat dalam kegiatan produksi agar bersedia bekerja dengan sebaik-baiknya. Ketua UPJ Jurusan Teknik Konstruksi Kayu sekaligus sebagai penanggung jawab UPJ memegang peran kunci dalam pelaksaan unit produksi. Fungsi pelaksanaan yang telah dijalankan oleh Ketua UPJ baru terbatas pada menerima pesanan produksi dari masyarakat. Fungsi pelaksanaan dijalankan sesuai dengan prinsipprinsip yang telah menjadi kesepakatan tidak tertulis atau kebiasaan di antara para pengelola UPJ Jurusan Teknik Konstruksi Kayu.

Langkah pertama dalam pelaksanaan UPJ dimulai dari penerimaan pesanan dari konsumen atau masyarakat. Konsumen yang memesan produksi bisa berasal dari sekolah sendiri atau dari warga di luar sekolah. Order atau pesanan dari Sekolah biasanya berupa perbaikan mebelair sekolah atau pembuatan mebelair baru. Order dari warga masyarakat dapat berupa mebelair atau kusen kayu. Hal ini sesuai dengan pernyataan AS sebagai berikut: "dapat job misalnya ada job dari luar saya tanyakan ini target waktunya kapan dan nanti mungkin bahan dari mana nanti saya tanyakan nanti kalau waktu juga mencukupi ya saya terima setelah itu nanti masuk kemudian direncanakan nanti saya target misalnya harus selesai satu bulan kedepan nanti saya target". (Hasil wawancara dengan AS, 28 Januari 2014). (W.S.A.2.1).

Kedua, ketua UPJ Jurusan Teknik Konstruksi Kayu membuat rancangan kerja mulai dari membuat desain atau model sesuai dengan permintaan pemesan, bahan yang dibutuhkan, lama pengerjaan dan biaya yang dibutuhkan untuk produksi. Ketua UPJ kemudian menyerahkan desain, target waktu penyelesaikan dan kriteria bahan kepada tukang untuk kerjakan. Apabila biaya produksi dapat dibiayai dari kas UPJ, maka ketua UPJ langsung berkoordinasi dengan kepala 
bengkel. Apabila biaya yang dibutuhkan cukup besar, maka ketua UPJ dan kepala bengkel berkoordinasi dengan bendahara sekolah agar UPJ dapat menggunaan uang kas dari sekolah. Hal ini diungkapkan dalam kutipan wawancara berikut. "Pak Sumari sebagai bendahara terutama kalau berhubungan dengan biaya kami minta pertimbangan Pak Sumari kalau kita dapat job agak lumayan ternyata kas UPJ kok tidak mampu kita rembugan Pak Sumari bagiamana baiknya bisa diterima atau tidak istilahnya kalau Pak Sumari iya, kan kalau beliau bilang iya beliau sudah tahu kalau UPJ harus bon uang dulu ke kas sekolah bias". (Hasil wawancara dengan AS, 16 Januari). (W.S.A.1.8).

Ketiga, kepala bengkel mengecek ketersediaan bahan dan kesiapan alat-alat yang dibutuhkan untuk produksi serta mengatur jadwal kegiatan. Apabila bahan tidak cukup, maka UPJ akan membeli bahan sesuai dengan produksi yang direncanakan. Alat-alat seperti mesin besar ataupun mesin tangan dicek jumlah dan fungsinya. Apabila ada yang rusak segera diperbaiki. Jadwal perlu diatur agar kegiatan di bengkel UPJ Jurusan Teknik Konstruksi Kayu berjalan seiring dengan kegiatan praktik siswa. Minimal, antara kegiatan produksi dan kegiatan praktik siswa tidak saling mengganggu.

Keempat, pelaksanaan unit produksi di ruang produksi oleh para tukang kayu. Jumlah tukang kayu yang dipekerjaan disesuaikan dengan order yang masuk, dan kelima, barang jadi yang sudah diproduksi diletakkan satu tempat masih dalam satu ruangan UPJ Jurusan Teknik Konstruksi Kayu. Apabila tempat tidak mencukupi, maka barang yang sudah jadi diletakkan di teras atau tempat lain yang memungkinkan sampai pesanan diambil. Prinsip kerja yang diterapkan dalam penyimpanan hasil produksi yaitu prinsip keamanan. Pengelola menempatkan produk begitu saja karena dipandang sudah aman.

Langkah-langkah pelaksanaan unit produksi tersebut memperlihatkan bahwa fungsi pelaksanaan yang diterapkan dalam mengelola UPJ Jurusan Teknik Konstruksi Kayu lebih menyerupai pelaksanaan proses produksi dari pada fungsi manajemen unit produksi. Hal ini memperlihatkan kelemahan manajemen dalam mengelola unit produksi yang ada di UPJ Jurusan Teknik Konstruksi Kayu.

Fungsi dari unit produksi dimaksudkan supaya siswa dapat dilatih untuk berwirausaha melayani pesanan dari luar. Sebagai tempat belajar berwirausaha, unit produksi belum berfungsi dengan baik karena keterlibatan siswa dalam kegiatan unit produksi sangat terbatas disebabkan beberapa sebab diantaranya siswa harus bergantian dengan tukang yang dipekerjakan di unit produksi kemudian siswa bisa ikut dalam kegiatan unit produksi terutaman dalam pembelajaran praktik ketika ada kesesuaian antara kompetensi yang ada dalam pelajaran dengan pesanan yang ada dari luar. Ketika kewalahan menerima pesanan dari luar, unit produksi lebih mengutamakan untuk pembelajaran siswa dari pada digunakan untuk kegiatan unit produksi. Sehingga produktifitas unit produksi menjadi terbatas. Unit produksi merupakan sarana peningkatan kemampuan dan ketrampilan sumber daya manusia di SMKN 2 Pengasih ini, baik guru ataupun siswa.

Pelaksanaan UPJ Jurusan Teknik Konstruksi Kayu belum dapat dijadikan sarana bagi sekolah untuk bisa membangun kerja sama dengan industri, meskipun pihak sekolah dapat mengikuti kemajuan kompetensi yang ada di industri. Namun demikian, pelaksanaan UPJ Jurusan Teknik Konstruksi Kayu sudah dapat untuk tempat belajar siswa untuk mengerjakan praktik serta menghasilkan dana. Pelaksanaan UPJ Jurusan Teknik Konstruksi Kayu ini sejalan dengan penelitian Daryanto (2012) tentang penyelenggaraan UP/J di SMK Umar Fatah Rembang telah dapat berjalan sesuai dengan perencanaan yaitu selain sebagai tempat belajar siswa untuk mengerjakan praktek dengan nuansa industri, juga dapat menghasilkan dana.

Pelaksanaan menghadapi kendala sarana tempat dan alat. Tempat menjadi kendala apabila unit produksi ingin mengembangkan menjadi lebih baik lagi. UPJ belum memiliki peralatan yang dapat memenuhi kebutuhan konsumen. Alat-alat yang tidak memadai menjadi kendala melayani pesanan tertentu. Sarana berupa alat semakin menjadi kendala 
apabila UPJ dijalankan seperti yang diidealkan pengelola UPJ. Pembelian alat di UPJ Jurusan Teknik Konstruksi Kayu belum menjadi prioritas sekolah sehingga tidak dianggarkan dalam APBD. Akibatnya kapasitas produksi yang rendah. Keberadaan bengkel yang sekaligus menjadi tempat praktik menjadikan unit produksi kurang efektif sebagai sebuah unit produksi yang profesional. Dilihat dari pengembangan kewirausahaan siswa, pelaksanaan UPJ Jurusan Teknik Konstruksi Kayu tampak kurang konsisten. Kondisi ini terjadi karena kurangnya komunikasi di antara para pengelola tentang pengembangan UPJ Jurusan Teknik Konstruksi Kayu. Menurut Usman (2014: p. 346), komunikasi bertujuan dan bermanfaat untuk mengubah perilaku (pola pikir, perasaan, dan tindakan). Berbagai hambatan terjadi karena adanya kurang komunikasi di antara para pengelola.

Pengawasan unit produksi seharusnya dilakukan sistematis, berdasarkan standar pelaksanaan dengan tujuan perencanaan, dilaksanakan dengan merancang sistem informasi umpan balik, membandingkan kegiatan nyata dengan standar, menentukan dan mengukur penyimpangan yang ada dan mengambil tindakan koreksi yang menjamin bahwa semua sumber daya yang dimiliki telah dipergunakan dengan efektif dan efisien. Pengawasan dilakukan melalui pengawasan kepada tukang, pengawasan bahan dan alat serta pengawasan keuangan.

Temuan peneliti memperlihatkan kegiatan pengawasan dalam pengelolaan UPJ Jurusan Teknik Konstruksi Kayu dilakukan secara sambil lalu karena di antara para pengelola setiap hari bertemu dan berkomunikasi, meskipun tidak selalu membicarakan UPJ Jurusan Teknik Konstruksi Kayu. Pengawasan dilakukan secara bersama-sama oleh pengelola, namun pengawasan tidak didasarkan pada pedoman yang jelas karena sebelumnya tidak pernah menyusun suatu rencana secara tertulis. Pengawasan berpedoman pada prinsip-prinsip yang telah menjadi kesepakatan tidak tertulis dan sudah biasa dijalankan di UPJ Jurusan Teknik Konstruksi Kayu prinsip keharmonisan kerja dan kualitas hasil, prinsip ketelitian dan ketepatan, dan prinsip transparansi dan akuntabilitas. Ketiadaan pedoman pengawasan ini bertentangan dengan konsep pengawasan harus direncanakan sebaik-baiknya (Hasibuan, 2014: p. 222) dan dengan terlebih dulu menyusun standar performans. Tidak adanya pedoman pengawasan tersebut karena UPJ Jurusan Teknik Konstruksi Kayu hanya menfokuskan pada fungsi sebagai tempat praktik bagi siswa, bukan sebagai sarana melatih kewirausahaan.

Pengawasan UPJ dilakukan oleh ketua UPJ sekolah dalam bentuk laporan bulanan. Ketua Jurusan Teknik Konstruksi Kayu juga melakukan pengawasan hanya terkait dengan pembelajaran, sedangkan ketua UPJ Jurusan Teknik Konstruksi Kayu hanya melakukan pengawasan terkait dengan pelaksanaan produksi untuk memenuhi pesanan. Pengawasan UPJ Jurusan Teknik Konstruksi Kayu sebagai sarana pembelajaran praktik bagi para siswa dilakukan oleh ketua Jurusan Teknik Konstruksi Kayu. Pengawasan UPJ Jurusan Teknik Konstruksi Kayu sebagai unit produksi yang bertujuan profit dilakukan oleh ketua UPJ Jurusan Teknik Konstruksi Kayu dan kepala bengkel. Sebagai unit produksi, kepala bengkel melakukan: (1) identifikasi titik-titik kegiatan, jadwal kegiatan, tugastugas lain, dan penyimpangan yang mungkin terjadi. (2) Peninjauan secara terus menerus agar pengawasan tetap berjalan, (3) mengukur stok bahan dan ketersediaan peralatan. Pengawasan ini berbeda dengan hasil penelitian Tawardjono (2011) yaitu pengawasan yang dilakukan di UPJ Otomotif dilakukan sejak perencanaan, saat kegiatan pelaksanaan, saat program kerja berlangsung, dan pengawasan setelah akhir program. Pengawasan di UPJ Jurusan Teknik Konstruksi Kayu tersebut tidak menyeluruh sejak awal perencanaan karena memang kegiatan produksi di UPJ Jurusan Teknik Konstruksi Kayu tidak didasarkan pada perencanaan yang utuh.

Pengawasan tidak didasarkan pada SOP ataupun standar tertentu, tetapi didasarkan pada identifikasi titik-titik kegiatan, jadwal kegiatan, tugas-tugas lain, dan penyimpangan yang mungkin terjadi. Hal ini sejalan dengan pendapat Fatah (2004: p. 101) yang menyebutkan bahwa pengawasan dilakukan 
melalui tiga tahap yaitu: (1) menetapkan standar pelaksanaan, (2) pengukuran pelaksanaan pekerjaan dibandingkan dengan standar, dan (3) menentukan kesenjangan antara pelaksanaan dengan rencana.

\section{SIMPULAN DAN SARAN}

\section{Simpulan}

Berdasarkan permasalahan, tujuan penelitian, hasil analisis, dan pembahasan yang dipaparkan pada bab-bab sebelumnya, dapat disimpulkan sebagai berikut:

Perencanaan UPJ Jurusan Teknik Konstruksi Kayu belum dilakukan dengan baik, UPJ sebagai sarana belajar sesuai jadwal pelajaran dan sebaga unit produksi hanya sesuai pesanan; kendala dalam perencanaan yaitu tidak ada rapat rutin pengelola yang khusus membahas UPJ dan lemahnya dokumentasi; tidak semua pengelola terlibat dalam perencanaan karena kepala bengkel dan Ketua UPJ hanya melibatkan wakil kepala sekolah dan bendahara sekolah hanya ketika ada pesanan dalam jumlah besar; pengorganisasian sumber daya manusia, bahan baku, peralatan dan keuangan belum cukup baik, meskipun sudah ada pembagian tugas, pendelegasian tugas dan wewenang, serta koordinasi; kendala dalam pengorganisasian yaitu kekurangan personalia, sarana yang masih terbatas, peralatan yang kurang, bahan baku dan keuangan yang terbatas serta koordinasi di antara pengelola; langkahlangkah pelaksanaan memperlihatkan fungsi pelaksanaan yang diterapkan lebih menyerupai pelaksanaan proses produksi daripada fungsi manajemen unit produksi; unit produksi belum berfungsi dengan baik sebagai sarana belajar karena keterlibatan siswa dalam kegiatan unit produksi sangat terbatas disebabkan harus bergantian dengan tukang yang dipekerjakan di unit produksi; pelaksanaan terkendala bengkel yang sekaligus menjadi tempat praktik menjadikan unit produksi kurang efektif sebagai sebuah unit produksi yang profesional; langkah dan prinsip pengawasan hanya diterapkan dalam hal pelaporan keuangan; pihak yang melakukan pengawasan yaitu ketua UPJ Sekolah, ketua UPJ jurusan, dan kepala bengkel sesuai dengan bidang kerja masing- masing; pengawasan hanya dilakukan pada proses produksi dan terkendala pada tidak adanya SOP ataupun standar tertentu.

\section{Saran}

Bagi SMKN 2 Pengasih sebaiknya unit produksi dapat dijadikan sebagai wahana pembelajaran berwirausaha dan pengembangan ketrampilan peserta didik. Unit produksi diharapkan dapat dikembangkan menjadi teaching factory sehingga peserta didik dapat berlatih dan belajar dalam lingkungan yang mirip dengan dunia usaha/dunia industri. Bagi pengelola unit produksi, sebaiknya selalu mengadakan koordinasi secara rutin yang khusus membahas pelaksanaan tugas dan fungsi UPJ baik sebagai sarana belajar praktik maupun sebagai unit produksi yang berorientasi keuntungan ekonomi.

\section{DAFTAR PUSTAKA}

Alptekin, S.E., Pouraghabagher, R., McQuaide,P. Poly, D.W.C. (2001). Teaching factory, proceeding of the 2011 Amercan Society for Engineering Education Annual Conference and Exposition, American Society for Engineering Education. Session 3563.

Bush, T., \& Coleman, M. (2000). Leadership and strategic management in education. London: A Sage Publication Company.

Depdiknas. (2003). Undang-Undang RI Nomor 20, Tahun 2003, tentang Sistem Pendidikan Nasional.

Fattah, Nanang. (2004). Landasan manajemen pendidikan, Bandung: Rosdakarya.

Gibson, Ivancevich, \& Donnely. (1996). Organisasi: perilaku, struktur, dan proses. Terjemahan Nunuk Andiarni dan Editor Lyndon S. Jakarta: Binarupa Aksara.

Handoko, Hani. (2003). Manajemen edisi 2. Yogyakarta: BPFE Fakultas Ekonomi UGM.

Hasibuan, Malayu, (2014). Manajemen sumber daya manusia. Jakarta: Bumi Aksara. 
Usman, Husaini, (2014). Manajemen, teori, praktik dan riset pendidikan. Jakarta: Bumi Aksara.

Kinici, A. \& Williams B.K. (2008). Management, New York: McGraw Hill.

Meyer, J.P, Stanley, D.J., Herscovitch, L. and Topolnytsky, .L, Affective, Continuance, and Normative Commitment to the Organization: A Meta-analysis of Antecedents, Correlates, and Consequences, Journal of Vocational Behavior 61, 20-52 (2002).

Muhammad, Arni. (2004). Komunikasi organisasi. Jakarta: Bumi Aksara.

Nasir, S.B, Strategy to Revitalize Technical and Vocational Education and Training (TVET): Management Perspectives, Global Journal of Management and Business Research Volume 12 Issue 23 Version 1.0 Year 2012.
Sudira, Putu. (2006) Kurikulum tingkat satuan pendidikan SMK, Jakarta: Depdiknas.

Robin, S. P., \& Coulter, M. (2014). Management $\left(3^{r d} e d\right)$. London: Pearson.

Darjanto, Singgih. (2012). Manajemen unit produksi dan jasa di sekolah Menengah Kejuruan Umar Fatah Rembang, Journal of Economic Education Vol 1, No 1 (2012).

Stoner, J.A.F, Freeman, R.E. \& Gilbert D.A. (1995). Management, Englewood Cliffs: Prentice hall.

Tawardjono, Us. (2012). Model unit produksi SMK di Daerah Istimewa Yogyakarta: studi kasus di SMKN 2 Pengasih Kulonprogo. Disertasi, Universitas Negeri Yogyakarta.

Zajda, J., \& Gamage, D.T., (2009). Decentralisation, school-based management, and quality, London: Springer Science. 